\title{
Changes in Total Soluble Proteins and in Some Enzymes during Morphogenesis of Sclerotium rolfsii
}

\author{
By I. CHET, NIRA RETIG AND Y. HENIS \\ The Hebrew University of Jerusalem, \\ Faculty of Agriculture, Rehovot, Israel
}

(Received 24 January 1972)

\section{SUMMAR Y}

Patterns of soluble proteins and enzymes were studied in the normal mycelium of the fungus Sclerotium rolfsii and at three stages of sclerotial formation. Significant changes in total soluble proteins were found during the morphogenetic process, as detected by gel isoelectric focusing. While no changes could be detected in acid phosphatase activity, peroxidase activity was higher in mature sclerotia than at other stages. Polyphenol oxidase activity was demonstrated with dihydroxyphenylalanine, catechol and tyrosine as substrates. While only one active isozyme of the latter enzyme was found in the mycelium, six different isozymes were detected in the mature sclerotia. Esterase isozymes, on the other hand, decreased significantly during morphogenesis.

\section{INTRODUCTION}

Sclerotium rolfsii grows as a septate filamentous fungus and differentiates to form sclerotia which are melanin-containing, thick-walled, resistant bodies (Chet, Henis \& Mitchell, 1967). Polyphenol oxidase activity was found to be involved in its melanin synthesis (Chet \& Henis, I969). Sclerotium production in $S$. rolfsii has been correlated with each of the following: inhibition of mycelial linear growth (Wheeler \& Waller, 1965); cutting of hyphal tips (Henis, Chet \& Avizohar-Hershenzon, 1965); and the addition to the growth medium of sulphydryl-group antagonists (Chet, Henis \& Mitchell, I966; Chet \& Henis, 1968). Since proteins are known to play an important role in the morphogenesis of various organisms (Kornberg, Spudich, Nelson \& Deutscher, 1968; Roth, Ashworth \& Sussman, 1968; Jockusch et al. 1970), it seemed of interest to follow the changes in total soluble proteins, in enzymes involved in sclerotial melanogenesis and in some other metabolic enzymes, before and during sclerotial maturation.

\section{METHODS}

Culture and growth conditions. The fungus Sclerotium rolfsii was isolated from sugar beet and grown on a defined synthetic agar medium (Okon, Chet \& Henis, 1972) at $30{ }^{\circ} \mathrm{C}$ for 7 days.

Protein extraction and determination. Proteins were extracted at four stages: growing mycelium (A), sclerotium initials (B), young white sclerotia (C), mature brown sclerotia (D), as shown in Fig. I. Samples ( 2 to $3 \mathrm{~g}$ ) were homogenized in $3 \mathrm{ml} \mathrm{O} \cdot \mathrm{I}$ M-tris- $\mathrm{HCl}$ buffer (pH 8.0) containing $0.1 \%$ ascorbic acid and $0.1 \%$ cysteine by means of an Ultra Turrax (Janke \& Kunkel KG, Staufen, Germany) for $5 \mathrm{~min}$ at $4{ }^{\circ} \mathrm{C}$. The homogenate was centrifuged at $\mathrm{I} 5000 \mathrm{~g}$ for $\mathrm{I} \mathrm{h}$ at $4{ }^{\circ} \mathrm{C}$ and the proteins remaining in the supernatant were used for electrophoresis. Protein content was estimated by the Folin reagent according 


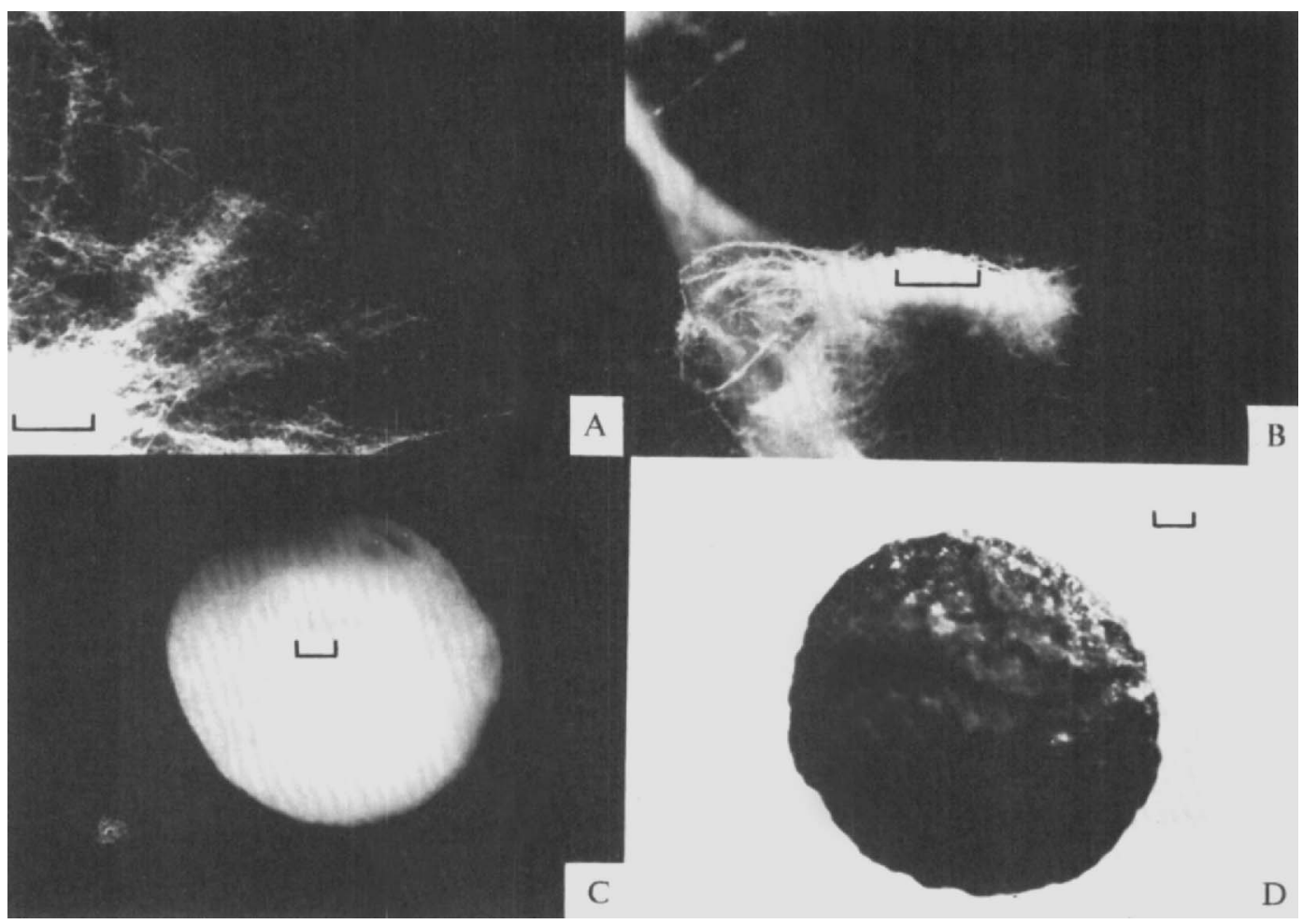

Fig. I. Morphological changes in Sclerotium rolfsii. (A) Mycelium, (B) sclerotium initial, (C) young, white sclerotium, (D) mature, brown sclerotium. Bars represents $0.5 \mathrm{~mm}$.

to Lowry, Rosenbrough, Farr \& Randall (I95I). The samples were then stored at $-20{ }^{\circ} \mathrm{C}$ before electrophoresis.

Electrophoresis, gel staining of proteins and isozyme identification. Isoelectric focusing (Wrigley, 1968) in $7.5 \%$ acrylamide gels was employed for protein separation. L.K.B. (Sweden) ampholine carrier containing $40 \%$ ampholites with $\mathrm{pH}$ ranging from 3 to ro was used. The gels $(8 \mathrm{~cm}$ long) were chemically polymerized by potassium persulphate. Protein samples were applied in 10\% sucrose under an ampholyte 'protective layer'. Each sample contained $500 \mu \mathrm{g}$ protein. Electrophoresis was carried out at $5{ }^{\circ} \mathrm{C}$ for $4 \mathrm{~h}$, applying $\mathrm{I} .5 \mathrm{~mA}$ per gel, gradually raising the voltage to $300-350 \mathrm{~V}$. The $\mathrm{pH}$ gradient in the gels was determined by cutting gels without protein into $10 \mathrm{~mm}$ slices. The slices were soaked in $2 \mathrm{ml}$ distilled water for $\mathrm{r} \mathrm{h}$ and the $\mathrm{pH}$ was measured with a Beckman Zeromatic $\mathrm{pH}$ meter. After electrophoresis, soluble proteins in the gels were stained with coomassie blue (Chrambach, Reisfeld, Wyckoff \& Zaccari, I967). Esterase isozymes were determined according to Desborough \& Peloquin (1967). Peroxidase isozymes were detected by immersing the gels in acetate buffer, $\mathrm{pH} 5.5$, containing $0.03 \%(\mathrm{v} / \mathrm{v})$ hydrogen peroxide and benzidine as the hydrogen donor. Acid phosphatase isozymes were detected according to Macko, Honold \& Stahmann (1967). Polyphenol oxidase (PPO) isozymes were tested according to Stafford \& Galston (I970). Substrates for PPO were 3,4-dihydroxyphenylalanine, catechol and L-tyrosine. Stained gels were scanned by a linear transport unit built on a Perkin-Elmer spectrophotometer Model I37 UV. Every experiment was repeated at least four times. 


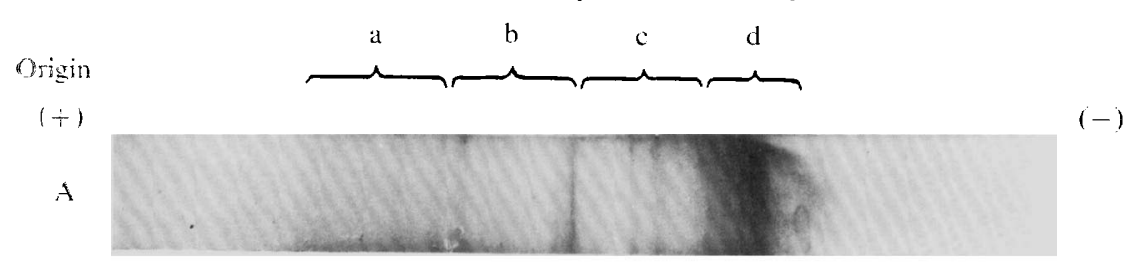

B
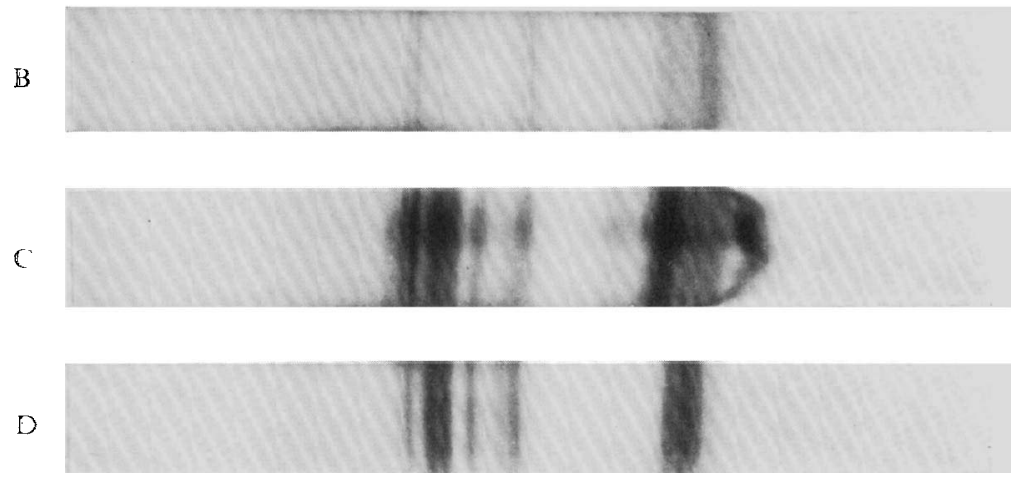

Fig. 2. Patterns of Sclerotium rolfsii soluble proteins separated by isoelectric focusing, extracted from: mycelium (A), initials (B), young sclerotia (C) and mature sclerotia (D).

\section{RESULTS}

Total soluble-protein patterns. Electrophoretic patterns of total proteins revealed clear differences between the developmental stages examined (Fig. 2). The patterns of stage A (growing mycelium) and B (sclerotium initials) were very similar. When the initials changed to young sclerotia, the bands in regions a and $\mathrm{c}$ almost disappeared, whereas more extensive stained bands appeared in regions $b$ and $d$. No significant differences were seen during sclerotium maturation although the bands in region $\mathrm{c}$ were lighter in gel $\mathbf{D}$ than in the others.

Polyphenol oxidase isozymes. Five major bands of PPO capable of oxidizing 3,4-dihydroxyphenylalanine, catechol and L-tyrosine were identified in young and mature sclerotia (Fig. $3 \mathrm{C}, \mathrm{D}$ ). The well-defined bands migrated to the region between $\mathrm{pH} 4$ and 6 . Whereas the mycelium showed none of these major bands (Fig. $3 \mathrm{~A}$ ), the sclerotium initials already showed the appearance of two (c and e) (Fig. 3B). All the tested samples showed a diffuse band (f) with low activity in the $\mathrm{pH} 7 \cdot 8$ region.

Peroxidase isozymes. Peroxidase activity was found only in mature sclerotia where one band was traced by gel scanning. No activity was found in gels of any other developmental stage (Fig. 4).

Esterase isozymes. Gels of all developmental stages showed esterase activity but marked differences were noticed in their isozyme patterns. Esterase extracted from mycelium showed four major bands. Spectrophotometer tracing of the gels at $350 \mathrm{~nm}$ is shown in Fig. $5 \mathrm{~A}$. The most active isozyme (a) migrated to the $\mathrm{pH} 4.7$ region, while the other three isozymes (b, c, d) appeared between $\mathrm{pH}_{5}$ and 6 . During initiation the activity of esterase significantly decreased (Fig. 5B). The major bands, a and c, showed very low activity, isozyme $\mathrm{d}$ disappeared, and the activity of isozyme $\mathrm{b}$, the only relatively active enzyme in that stage, decreased slightly. Esterase activity in young and mature sclerotia, indicated no changes compared with the initiation stage (Fig. $5 \mathrm{C}, \mathrm{D}$ ). 


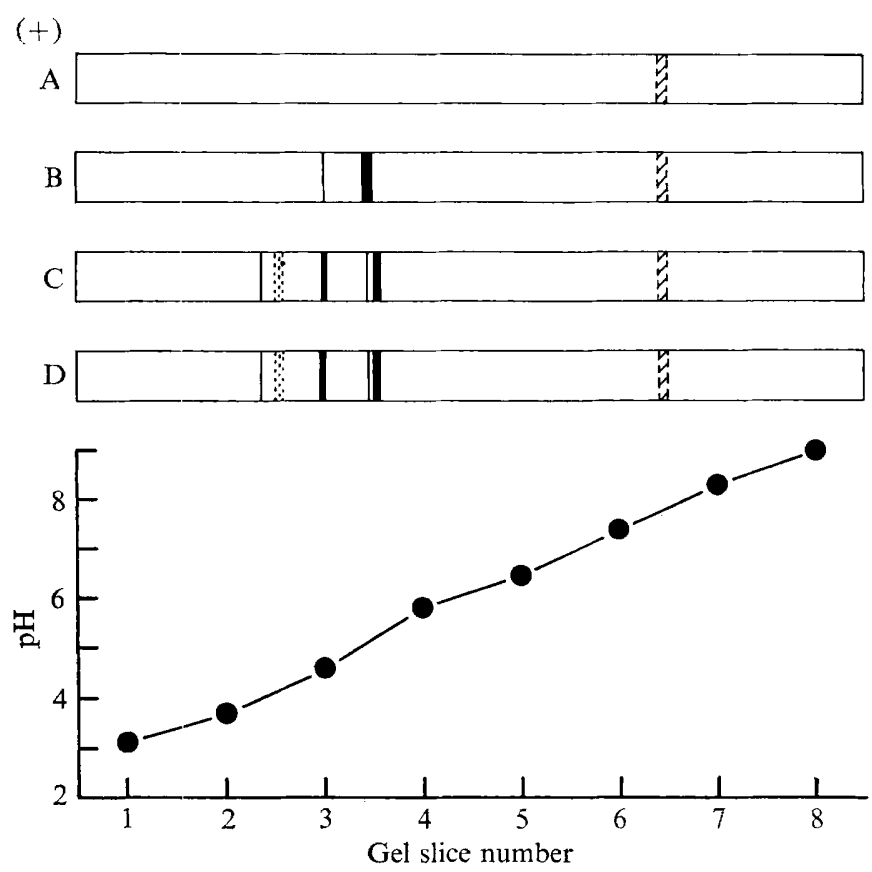

Fig. 3. Diagrams of electrophoretic patterns of polyphenol oxidase extracted from mycelium (A), initials (B), young sclerotia (C) and mature sclerotia (D).

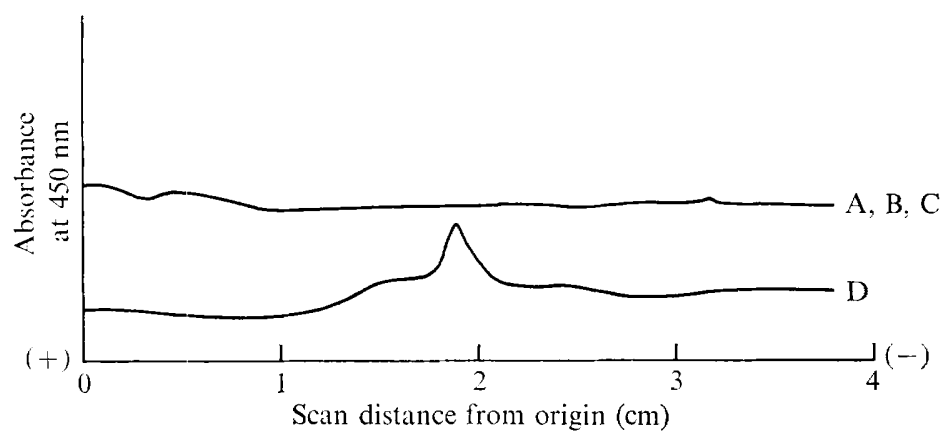

Fig. 4. Gel-scanner tracing of electrophoretic patterns of peroxidase extracted from mycelium (A), initials (B), young sclerotia (C) and mature sclerotia (D).

Acid phosphatase isozymes. No differences in the activity of this enzyme could be detected during sclerotium formation in Sclerotium rolfsii. Only one wide, dark band was found in the region of $\mathrm{pH} 3 \cdot 0$.

\section{DISCUSSION}

Sclerotium formation in Sclerotium rolfsii is a complex morphogenetic process in which both structural and biochemical events take place. Some of these changes were followed in this study.

In the patterns of total soluble protein there was a clear-cut difference between the initiation stage (B) and young sclerotia (C), but not between mycelium (A) and initiation (B) or between young (C) and mature sclerotia (D). However, by examining isozymes of 


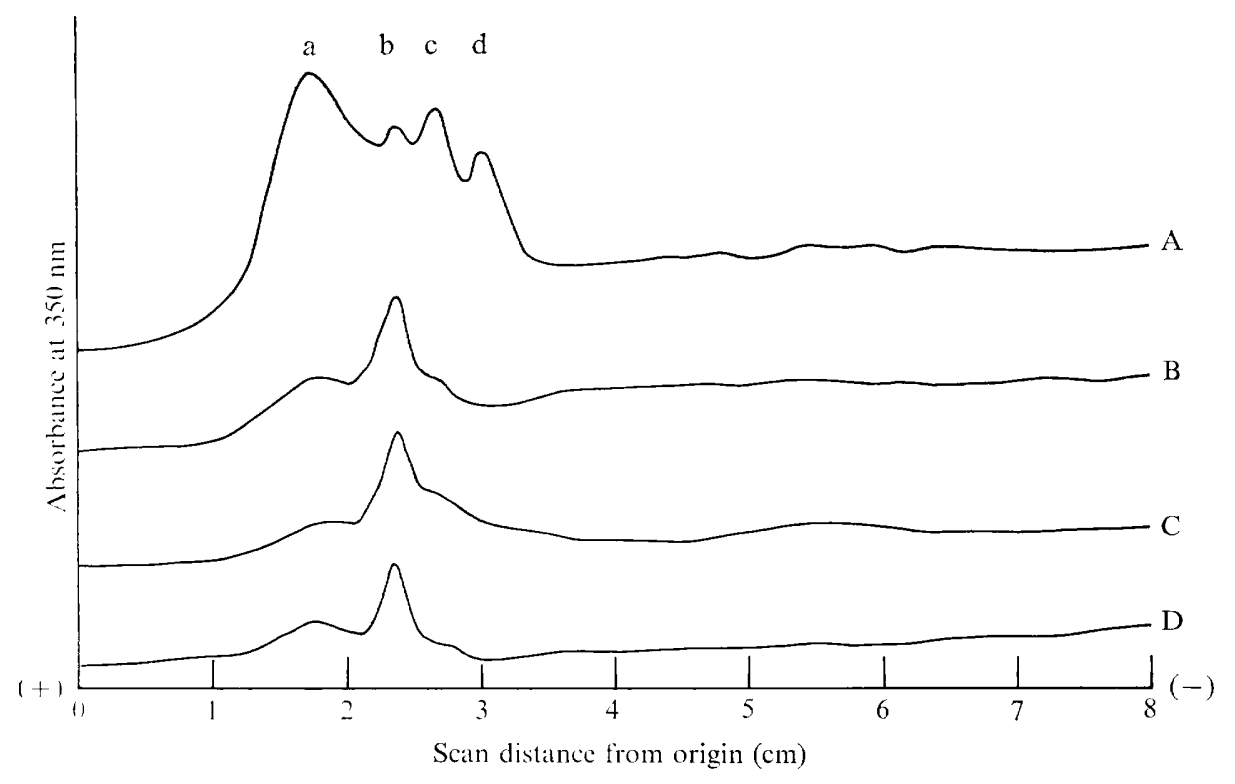

Fig. 5. Gel-scanner tracing of electrophoretic patterns of esterase extracted from mycelium (A), sclerotium initials (B), young sclerotia (C) and mature sclerotia (D).

several enzymes it was demonstrated that each developmental stage had its specific pattern. Acid phosphatase was the only enzyme tested which showed no differences during morphogenesis. Only one isozyme of peroxidase was found in gels of mature sclerotia but not in gels of other stages. The most prominent changes were observed in PPO isozymes. This enzyme had been found to be involved in melanogenesis in Sclerotium rolfsii (Chet \& Henis, I968). The isoelectric focusing technique revealed the appearance of new isozymes during sclerotium formation, all capable of oxidizing 3,4-dihydroxyphenylalanine, catechol and tyrosine. Although PPO isozymes were detected in very early developmental stages (B), it seems that the presence of its activity does not necessarily mean that melanogenesis will occur (stages A, B, C) unless all the isozymes or substrates reach a minimal level essential for the process (stage D).

The pattern of esterase isozymes during morphogenesis of Sclerotium rolfsii showed differences, although of unknown physiological significance. Of the four isozymes appearing in the mycelium, only one kept most of its activity during initiation and sclerotium formation. Enzymes such as esterases can perhaps be used as indicators of differentiation before the morphological alterations. Further information on biochemical changes during sclerotium production is required in order to understand the processes involved in the morphogenesis of Sclerotium rolfsii.

\section{REFERENCES}

Chet, I. \& Henis, Y. (I968). The control mechanism of sclerotial formation in Sclerotium rolfsii. Journal of General Microbiology 54, 23I-236.

CHet, I. \& Henis, Y. (I969). Effect of catechol and disodium EDTA on melanin content of hyphal and sclerotial walls of Sclerotium rolfsii Sacc. and the role of melanin in the susceptibility of these walls to $\beta$-(I-3) glucanase and chitinase. Soil Biology and Biochemistry I, I3 I-1 38 .

Chet, I., Henis, Y. \& Mitchell, R. (I966). The morphogenetic effect of sulphur-containing amino acids, glutathione and iodoacetic acid on Sclerotium rolfsii Sacc. Journal of General Microbiology 45, 54 I-546.

Chet, I., Henis, Y. \& Mitchell, R. (I967). Chemical composition of hyphal and sclerotial walls of Sclerotium rolfsii Sacc. Canadian Journal of Microbiology 13, 137-I4I. 
Chrambach, A., Reisfeld, R. A., Wyckoff, M. \& Zaccari, J. (I967). A procedure for rapid and sensitive staining of protein fractionated by polyacrylamide gel electrophoresis. Analytical Biochemistry 20, I50-I 54 .

Desborough, S. \& Peloquin, S. J. (I967). Esterase isozymes from Solanum tubers. Phytochemistry 6,989-994.

Henis, Y., Chet, I. \& Avizohar-Hershenzon, Z. (I965). Nutritional and mechanical factors involved in mycelial growth and production of sclerotia by Sclerotium rolfsii in artificial medium and amended soil. Phytopathology 55, 87-91.

JockusCh, B. M., SAuer, H. W., Brown, D. F., Babcock, K. L. \& RusCH, H. P. (1970). Differential protein synthesis during sporulation in the slime mold Physarum polycephalum. Journal of Bacteriology 103, $356-363$.

Kornberg, A., Spudich, J. A., Nelson, D. L. \& Deutscher, M. P. (1968). Origin of proteins in sporulation. Annual Review of Biochemistry 37, $5 \mathrm{I}-78$.

Lowry, O. H., Rosebrough, N. J., Farr, A. L. \& Randall, R. J. (I95I). Protein measurement with the Folin phenol reagent. Journal of Biological Chemistry 193, 265-275.

Macko, V., Honold, G. R. \& Stahmann, M. A. (1967). Soluble protein and multiple enzyme forms in early growth of wheat. Phytochemistry 6, 465-47I.

Okon, Y., Chet, I. \& Henis, Y. (I972). Lactose-induced synchronous sclerotial formation in Sclerotium rolfsii and its inhibition by ethanol. Journal of General Microbiology 7r, 465-470.

Roth, R., Ashworth, J. M. \& Sussman, M. (1968). Periods of genetic transcription required for the synthesis of three enzymes during cellular slime mold development. Proceedings National Academy of Sciences of the United States of America 59, $1235-1242$.

StAFFord, H. A. \& GALSTON, A. W. (1970). Ontogeny and hormonal control of polyphenoloxidase isozymes in tobacco pith. Plant Physiology 46, 763-767.

WhEELER, B. E. J. \& W ALLER, J. M. (1965). The production of sclerotia by Sclerotium rolfsii. II. The relationship between mycelial growth and initiation of sclerotia. Transactions British Mycological Society 48 , 303-3r4.

WRIGLEY, C. (1968). Gel electrofocusing - a technique for analyzing multiple protein samples by isoelectric focusing. Science Tools I5, I7-23. 